\title{
CONTINUOUS QUALITY IMPROVEMENT DALAM MANAJEMEN MUTU
}

Oleh ;

\section{Siswanto 1}

Mahasiswa Manajemen, Fakultas Agama Islam Universitas Nurul Jadid

Email : siswanto.iksana@gmail.com

\begin{abstract}
Abstrak
Continuous Quality Improvement (CQI) atau disebut juga Perbaikan mutu berkesinambungan atas kinerja oraganisasi secara menyeluruh hendaknya di jadikan sebagai patokan tetap dari oraganisasi. Proses berkesinambungan merupakan prinsip dasar yang paling fundamental di mana mutu adalah sebagai pusatnya. proses ini merupakan pelengakap dan yang menghidupkan proses, dan juga prinsip fokus pada customer atau pelanggan.

Perbaikan yang berkesinambungan berkaitan dengan komitmen dan proses (continuous process improvement) kometmen terhadap kualitas di mulai dengan pernyataan dedikasi pada misi dan visi bersama, serta pemberdayaan semua partisipan untuk secara inkremental mewujudkan visi tersebut.

Perbaikan mutu yang berkesinambungan bergantung pada dua unsur. Pertama, mempelajari proses alat, dan keterampilan yang tepat. Kedua Menerapkan keterampilan baru pada small achiveable projects.

Namun, upaya perbaikan kualitas secara berkesinambungan dalam lembaga pendidikan ditentukan oleh sumber daya manusia sebagai pemberi pelayanan pendidikan yang berkualitas pada customer.
\end{abstract}

1. Mahasiswa Aktif Universitas Nurul Jadid 
Kualitas kinerja yang baik dan berkelanjutan dapat diraih jika kita bekerja berdasarkan kebutuhan riil pemangku kepentingan (stakeholder), dimana kebutuhan tersebut bersifat tidak tetap (dinamis) dari berbagai waktu.

Kata Kunci: Sumber daya manusia, Berdasarkan customer, kualitas kinerja, perbaikan mutu berkelanjutan, dan lembaga pendidikan.

\section{A. Pendahuluan}

Pada hakikatnya kehidupan manusia selalu mengarah pada tinkatan masa atau fase yang semakin berkembang dan meningkat dari waktu ke waktu, dalam konteks individuil maupun sosial. Kecinderungan tersebut mendapatkan penguwatan dalam beberapa segi, seperti teiologis dan sosiologis. Orang-orang muslim umumnya memahami sebuwah doktrin bahwa "hidup itu harus lebih baik hari ini dari kemarin, dan esok harus lebih baik dari hari ini”. Dalam kehidwpan bermasyarakat, seseorang pemalas yang tidak mawu bekerja memperbaiki nasibnya akan mendapatkan hukwuman sosial dalam berbagai bentuk.

Perubahan zaman yang sangat singkat, bersamaan dengan itu semakin tingginya persaingan atau tingkat kompetisi karena di veresifikasi pekerjaan yang bertambah semakin spesifik, yang dengan sendirinya mempertajam tingkat kompetisi mutu dari setiap bidang pekerjaan yang ada. Dalam kontesk itu berlaku hukum bahwa "siapa yang bermutu tinggi akan menjadi pemenang di puncak, sebaliknya yang kualitasnya rendah akan tergilas zaman dan tertinggal dari yang lain". Mekanisme perlombaaan tersebut menganjurkan kepada kita untuk selalu siap siaga menghadapi kondisi apapun, memahami gerak perubahan zaman dan mengendalikannya untuk keluar sebagai peraih kemenangan . 
Fakta-fakta sosial tersebut menjadi contoh betapa berartinya kehidupan yang progresif dan dinamis bagi umat manusia, yang nantinya dengan sendirinya menjadi hukum sosiologies yang tak tertulis dan mungkin menjadi panutan etika. Berangkat dari pandangan fundamen tersebut, mulailah manusia melalakukan aktifitas yang mengarah pada perbaikan mutu secara berkelanjutan.

\section{B. Aktivitas Perbaikan Mutu Berkesinambungan}

Dalam berbagai organisasi, orang bekerja untuk memenuhi spesifikasi dan merasa puwas apabila pekerjaan mereka sesuai dengan patokan rencana atau standare yang telah ditetapkan. Jadi selama masalah belum timbul, maka tidak perlu diatasi. Namun, perbaikan mutu berkesinambungan tidak sekedar mengatasi dan memecahkan masalah, tetapi juga memperbaiki penyebab penyimpangan dari standare yang ditetapkan. Sudah barang tentu perbaikan mutu berkesinambungan tidak menjadi lebih gampang karena semakin banyak perbaikan yang harus diselesaikan ${ }^{2}$. Ada beberapa aktivitas dalam perbaikan mutu berkesinambungan, yaitu:

1. Komonikasi

Komonikasi merupakan aspek yang sangat inten dalam perbaikan mutu berkesinambungan. Tanpa adanya komonikasi ,perbaikan berkesinambungan tidak dapat berjalan dengan baik. Komonikasi berguna untuk bertukar informasi sebelum, selama, dan sesudah adanya usaha perbaikan mutu.

2. Memperbaiki masalah yang jelas dan nyata

2 . Fandy Tjiptono dan Anastasya Diana, Total Quality Manajement, ( C.V. ANDI OFFSET:2003: Yokyakartata ) Hal. 266. 
Permasalahan yang terjadi seringkali belum jelas, sehingga diperlukan riset untuk mengidentifikasi dan juga mengatasinya. Oleh karena itu pendekatan ilmiyah begitu penting dalam TQM.

3. Memandang ke pangkal

Memandang ke pangkal berarti mencari penyebab suwatu masalahnya, bukan gejalanya atau dampaknya .

4. Mendokumentasi perkembangan dan problem

Pendukumentasian masalah yang pernah ada dan kemajuan dilakukan agar apabila di kemudiyan hari kita menjumapai masalah yang sama, maka pemecahannya dapat dilakukan dengan cepat dan tepat.

5. Memantau perkembangan dan perubahan

Pemantauan secara berkala dan objektif terhadap kinerja suatu proses setelah diadakan perubahan perlu dilakukan, karena kadang kala solusi yang diajukan untuk salah satu masalah belum tentu memecakan masalah tersebut secara tuntas sebagai antisipasi. ${ }^{3}$

\section{Konsep Dasar Continuous Improvement}

Perbaikan mutu terus-menerus atau perbaikan mutu berkesinambungan merupakan salah satu unsure penting dan fundamental dari TQM. Konsep perbaikan mutu terus-menerus harus diterapkan, baik terhadap proses, maupun orang yang melaksanakakan perbaikan itu sendiri.

Konsep perbaikan mutu terus menerus dibentuk berdasarkan pada urutan serta langkah-langkah kegiaatan yang berkaitan dengan hasil output seperti produk berupa barang dan jasa atau alumni dalam pendidikan.. Tujuan pertama perbaikan secara terus menerus ialah proses yang handal, dalam arti

\footnotetext{
${ }^{3}$. Fandy Tjiptono dan Anastasya Diana, Total Quality Manajement, ( C.V. ANDI OFFSET:2003: Yokyakartata ) Hal. 267.
} 
bahwa dapat memproduksi yang diinginkan setiap saat tanpa variasi yang diminimumkan. Apabila keragaman telah dibuwat minimum dan hasilnya belum dapat diterima maka tujuan kedua dari perbaikan proses ialah merancang kembali proses tersebut untuk memproduksi output yang lebih dapat memenuhi kebutuhan costumer, agar pelanggan puas.

TQM diwujudkan dalam rangkaian proyek-proyek berskala kecil. Filosofi TQM memang berskala besar, inspirasional dan meyeluruh, namun implementasi praktisnya justru berskala kecil, sangat praktis, dan berkembang. Intervensi drastis tidak sesuai dengan semangat perubahan yang ada dalam TQM. Skema yang muluk-muluk tidak akan menimbulkan kemajuan, sebab hal sedemikian sering terjebak pada kurangnya sumber daya, dan buntunya sumberdaya bisa mengakibatkan sinisme dan ketidakpuasan.

Esensi Kaizen adalah proyek kecil yang berupaia untuk membangun kesuksesan dan kepercayaan diri, dan mengembangkan dasar peningkatan selanjutnya. Sebuah institusi harus melakukan aktifitas dengan teliti, proses demi proses, isu demi isu. Dalam jangka waktu tertentetu metode ini lebih berhasil daripada langsung melakukan perubahan dalam skala besar. Hal lain yang perlu ditekankan untuk melakukan perbaikan mutu adalah bahwa implementasi tersebut tidak harus menjadi prosese yang mahal. Menghabiskan uang tidak dengan sendirinya bisamenghasilkan mutu, meskipun dalam tahap-tahap tertentud apat membantu. ${ }^{4}$

Selanjutnya untuk mewujudkan paradigma continuous improvement, harus ditanamkan personal value yang cocok dengan paradigma tersebut,

\footnotetext{
4. Edward Sallis, Total Quality Management in Education, Manajemen Mutu Pendidikan, (Jogjakarta: IRCiSoD, 2011), hlm. 78.
} 
yakni: kejujuran, kerendahan hati, kerja keras, kesabaran, keterbukaan dan keberanian. $^{5}$

\section{Kesimpulkan}

Perbaikan mutu berkesinambungan adalah prinsip dasare di mana mutu menjadi pusatnya proses ini merupakan pelengakap dan yang menghidupkan prosese orientasi proses dan prinsip fokus pada costemer.

Perbaikan mutu yang berkesinambungan berkaitan dengan komitmen (continuous quality improvement atau CQI ) dan proses (continuous process improvement) kometmen terhadap kualitas di mulai dengan pernyataan dedikasi pada misi dan visi bersama, serta pemberdayaan semua partisipan untuk secara inkremental mewujudkan visi tersebut.

Perbaikan mutu yang berkesinambungan bergantung pada dua unsur. Pertama, mempelajari proses alat, dan keterampilan yang tepat. Kedua Menerapkan keterampilan baru pada small achiveable projects.

Namun, upaya perbaikan kualitas secara berkesinambungan dalam lembaga pendidikan ditentukan oleh sumber daya manusia sebagai pemberi pelayanan pendidikan yang berkualitas pada customer.

Namun, upaya perbaikan kualitas secara berkesinambungan dalam lembaga pendidikan ditentukan oleh sumber daya manusia sebagai pemberi pelayanan pendidikan yang berkualitas pada customer.

Kualitas kinerja yang baik dan berkelanjutan dapat diraih jika kita bekerja berdasarkan kebutuhan riil pemangku kepentingan (stakeholder), dimana kebutuhan tersebut bersifat tidak tetap (dinamis) dari waktu ke waktu.

\footnotetext{
${ }^{5}$ Diktat Manajemen Mutu Versi 1/10, hlm. 22.
} 


\section{Daftar pustaka}

Dorothea Wahyu Ariani, Manajemen Kualitas Pendekatan Sisi Kualitatif, (Jakarta:

Ghalia Indonesia, 2003),

Edward Sallis, Total Quality Management in Education, Manajemen Mutu Pendidikan, (Jogjakarta: IRCiSoD, 2011),

Fandy Tjiptono dan Anastasya Diana, Total Quality Manajement, ( C.V. ANDI OFFSET:2003: Yokyakartata ).

Mundiri, A., Laili, I. N., Hasanah, N., \& Humairoh. (2018). Pengembangan Media Pembelajaran Pendidikan Agama Islam; Konsepsi, Konvergensi, dan Implementasi. Probolinggo: Pustaka Nurja. 